УДК 94(47).083

\title{
РОССИЙСКАЯ ФИЛАНТРОПИЯ И ПЕРВАЯ МИРОВАЯ ВОЙНА (НА МАТЕРИАЛАХ ТЕРСКОЙ ОБЛАСТИ)
}

В статье исследуется содержание благотворительной практики в Терской области Российской империи в условиях участия страны в Первой мировой войне. На конкретном историческом материале выявлены основные направления и формы сотрудничества общества и власти в оказании помощи пострадавшим от войны и участникам военных действий. Исследована предметная филантропическая деятельность как ранее действовавших на территории области благотворительных организаций, так и вновь созданных, в том числе в качестве отделений ряда российских благотворительных организаций, возникших по результатам начала военных действий, а также благотворительная активность отдельных граждан. Показано, что, собирая пожерт- вования, открывая приюты, лазареты, мастерские для профессиональной реабилитации воинов-инвалидов снабжая фронтовиков самым необходимым, помогая беженцам, готовя медсестер для работы в госпиталях, общество, в самых разных его слоях, и местная власть, вдохновляемые примером многих членов императорской фамилии, проявили единодушие в стремлении помочь стране и армии пережить время военных невзгод и лишений.

Ключевые слова: благотворительность, Первая мировая война, Терская область, раненые, инвалиды, сироты, беженцы, помощь, благотворительные ведомства и общества, органы власти и городского самоуправления.

\section{T. E. Pokotilova}

\section{RUSSIAN PHILANTHROPY AND THE FIRST WORLD WAR (ON MATERIALS OF THE TEREK REGION)}

The article studies charitable practices in the Terek region of the Russian Empire during World War I. With the reference to particular historical material the author reveals the main forms and directions of cooperation between the authority and society in helping war-stricken and participants of warfare. The author studies philanthropic activities of charitable organizations, previously acted and newly established, including branches of a number of organizations that emerged at the beginning of World War I. For another thing, the charitable activities of individual citizens were explored. Collecting donations, opening shelters, hospitals,

Современная отечественная историческая наука уже немыслима без офрормившегося за последние десятилетия целого направления исследований, связанных с историей российской благотворительности. Написаны и защищены более сотни кандидатских и не менее двух десятков докторских диссертаций, регулярно проводятся представительные научные и научно-практические конференции, в т. числе международного характера. Публикуются монограффии [2; 4; 5; $9 ; 11 ; 12 ; 14 ; 18-21 ; 27$ и др.] и научные статьи, предметами исследования которых становятся направления благотворительной деятельности в дореволюционной России, отдельные аспекты истории благотворительности как общероссийского социокультурного феномена. В них также реконструируются исторические модели благотворения в формате деятельности отдельных workshops for vocational rehabilitation of disabled soldiers, supplying front-line soldiers with the most necessary, helping refugees, preparing nurses for work in hospitals, society, in its most diverse layers, and local authorities, inspired by many members of the imperial family, showed unanimity in an effort to help the country and the army survive the time of military adversity and deprivation.

Key words: charity, World War I, Terek region, disabled people, orphans, refugees, help, charities, authorities, municipality.

личностей, сословий, церкви, общественных организаций и целых благотворительных ведомств на общероссийском, региональном и муниципальном уровнях; изучается деятельность благотворительных заведений и учреждений; исследуются проблемы объединения благотворительных усилий участников благотворительного процесса и т.д. Масштаб и научное качество состоявшихся исследований в ссфере истории российской благотворительности, в свою очередь, вызвали к жизни специальные историографические труды [17: 22; 28-31], отдельным аспектом которых стал и анализ состояния разработки проблем истории благотворительной деятельности в условиях военного времени.

Специальных работ, посвященных истории благотворительности в Терской области в годы Первой мировой войны, пока не создано. При 
этом отдельные ее аспекты получили фррагментарное освещение в трудах Х. А. Атабиева [1] А. А. Бесоловой [3], Т. А. Корниенко [6], В. С. Краснокутского [7], Ю. В. Нагорной [8], Е. В. Омылаевой [10], Т. Е. Покотиловой [15;16], Ч. В. Тигиева [25]

Количество и масштабы военных конфликтов в которых Россия становилась одной из участвующих сторон на протяжении своей истории, определили высокую степень значимости благотворительного участия в решении проблем, связанных с преодолением последствий этих конфликтов и помощью в обеспечении воинов самым необходимым. Именно поэтому власть стремилась инициировать и возглавить здесь благотворительную активность, часто сливаясь с обществом в сфере оказания подобной помощи. Г. Н. Ульянова мотивированно настаивает на том, что в «отношении деятельности многочисленных общественных организаций в период Первой мировой войны термин «благотворительность» несколько условен. Чистой благотворительностью является лишь деятельность, целиком осуществляемая на пожертвования и силами добровольцев, а в годы войны наблюдался симбиоз власти и общества в сорере оказания помощи: частные пожертвования поступали в филантропические ведомства, имевшие также государственные дотации, и, наоборот субсидии из казны переходили к местному самоуправлению, частным филантропическим обществам ) [26; с. 230].

Источники свидетельствуют, что Терская область не стала здесь исключением. При личной инициативе и под патронажем членов мператорской семьи, под руководством центральной и местной властей, при деятельном участии Всероссийского союза городов многие жители области частным образом либо в составе различных благотворительных организаций стали активными участниками движения по сбору пожертвований и организации работы детских и иных приютов, бесплатных столовых, мастерских трудовой помощи для инвалидов войны и др.

Практически, на второй неделе после вступления России в войну императором издается указ о создании в стране центрального органа по организации помощи семьям воинов - Верховного совета по призрению семей лиц, призванных на войну, а также семей раненых и павших воинов [13] Эфффективность действий этого руководящего органа планировалось обеспечить, в первую очередь, составом его членов. В него вошли, кроме непосредственного руководителя - императрицы Александры Федоровны, председатель Совета министров, председатель Государственного совета, председатель Государственной думы, основные министры, руководители Российского общества Красного Креста и ряда других крупных благотворительных ведомств, главноуполномоченные Всероссийского городского и Всероссийского земского союзов. Определив нормы пособий для членов семей и пострадавших воинов, утвердив механизм определения перечня получателей пособий, Совет начал работу по организации сбора средств на них.
Исполнение этих решений в Терской области осуществлялось по линии местной власти, органов городского самоуправления, уже действовавших до этого на ее территории благотворительных организаций и вновь создаваемых, в том числе в качестве отделений ряда российских благотворительных организаций, возникших по результатам начала военных действий, а также отдельными гражданами.

Фонды Центрального государственного архива Республики Северная Осетия - Алания (ЦГА РСО-Алания) содержат массу документов изучаемого периода, связанных с действиями названных субъектов благотворительного движения

Так, например, известно, что практически в первые дни войны в Петрограде создается Кавказский Комитет ее императорского величества великой княгини Елизаветы Федоровны по оказанию благотворительной помощи пострадавшим от войны. Объявленная им цель - «...изыскание средств для оказания помощи семьям лиц, призванных на войну, а также всем, так или иначе пострадавшим от войны: увечным воинам, беженцам с мест, входящих в район военных действий и т.п.» [35; л. 134 об.]. Во Владикавказе создается областной комитет этой организации, а в Пятигорске, Грозном, Моздоке, Кизляре, Нальчике, Ведено и Хасав-Юрте - местные и уездные отделы Комитета. Председателем Терского областного комитета становится генерал-лейтенант Флейшер - начальник области [35; с. 392]. Для организации работы с максимально возможной эфффективностью он принимает решение о создании в местных и уездных отделах Комитета комиссий по работе по отдельным направлениям. Сохранились многочисленные отчеты этих комиссий и решения, к примеру, органов городского самоуправления в качестве реакции на эти отчеты. Как, например, содержание отчета одной из комиссий по призрению семейств запасных и ратников стало предметом обсуждения на заседании Городской думы Владикавказа с принятием решения: «...3. ассигновать в распоряжение исполнительной комиссии на дело призрения семейств запасных нижних чинов и ратников государственного ополчения, в качестве безвозмездного пособия 2000 руб. из городского капитала» [34; л. 148 об.].

На территории области работали и местные отделы созданного в 1915 г. Комитета ее императорского величества великой княгини Марии Павловны по помощи раненым и потерявшим на войне способность к труду воинам. Не ограничиваясь сбором пожертвований и выдачей разовых пособий раненым и освобожденным от службы воинам, местные отделы Комитета во Владикавказе и Пятигорске работали в направлении организации мастерских для искалеченных войной солдат. Председателем комиссии по организации т.н. Мариипавловских мастерских в Терской области стал владикавказский воинский начальник полковник Михайлов, товарищем председателя А. В. Замковой. В мастерских инвалиды обучались ремеслу, с помощью которого они в дальнейшем смогли бы зарабатывать на жизнь. В период 
обучения они обеспечивались жильем, питанием и имели возможность зарабатывать. Обучали в терских мастерских, преимущественно, сапожному и портняжному делу. После завершения обучения учившиеся имели право выбора: уехав в родное село, открыть свое дело, либо продолжить работу по месту обучения. Интенсивность и качество работы мастерских для обучения инвалидов-воинов в области была оценена на самом высоком уровне - Председатель комиссии Михайлов в 1917 г. был представлен к награде [36; л. 193 - 193 об.]. Существовали эти мастерские на пожертвования местного населения, но, в большинстве своем, что касается оплаты производственных помещений, сырья для работы, еды и одежды для обучающихся, финансы выделялись Комитетом Марии Павловны в Петрограде. А самыми активными жертвователями на месте стали члены Грозненского дамского кружка «Чашка чая». Во много благодаря их помощи был открыт во Владикавказе 1 декабря 1916 г. приют-мастерская на 15 человек. Председателем приюта стал войсковой старшина Рогожин, а казначеем - жена полковника О. И. Фричинская [36; л. 83 - 83 об].

Женская составляющая в благотворительной помощи пострадавшим от войны была достаточно велика. По следам происходивших военных событий, в городах Терской области в 1915 г. возникли и начали активно работать, как и в Грозном, Дамские кружки «Чашка чая», ставившие своей непосредственной целью «...собирание средств для обращения таковых на помощь лицам, в той или иной форме пострадавшим от настоящей войны, а также участникам еe, нуждающимся в этом». [33; с. 20]. Как правило, членами этих организаций были жены военных и чиновников, имевшие определенный образовательный уровень. Так, например, среди учредительниц Владикавказского дамского кружка «Чашка чая» для помощи жертвам войны и участникам ее были жена подполковника О. И. Тимченко, жена присяжного поверенного М. К. Скуридина, дворянка Е. М. Андреевская, жена надворного советника Е. Г Гасумянц, жена присяжного поверенного 3. А. Малкоедова, жена прапорщика О. Н. Журавлева, дворянка В. Н. Котюхова, жена присяжного поверенного А. В. Ходамицкая, дочь действительного тайного советника Н. П. Загорская, жена подьесаула Л. И. Ходамицкая [33; л. об.]

Конечно же, наиболее активными как в практической деятельности по оказанию благотворительной помощи пострадавшим от войны, так и в пожертвованиях были, прежде всего те, кто имел для этого досуг и средства. Объемы, к примеру, финансовых вливаний в дело помощи семьям запасных, призванных на действительную службу со стороны представителей т.н. торгово-промышленного класса Терской области были таковы, что Владикавказская городская дума 10 июня 1915 г собралась на специальное заседание. После доклада о масштабах пожертвований и оглашении списка жертвователей, делавших это под эгидой городского комитета представителей торгово-промышленного класса, гласные Думы выразили «...глубокую благодарность торгово-промышленному классу города Владикавказа за те крупные жертвы, которые он принес для обеспечения семейств запасных, защитников целости и славы России...» [34; л. 194 об.].

Сам Владикавказский городской голова Г. В. Баев всегда отличался активной гражданской позицией и много лично сделал для развития общественной благотворительности в области. В условиях военного времени он активизировал собственную практику выступления с благотворительными лекциями на животрепещущие темы. К примеру, газета “Терские ведомости» от 10 апреля 2015 г. опубликовала очередное приглашение на такую лекцию: «Сегодня, 10 апреля, в зале коммерческого собрания состоится лекция И. В. Баева: “Великая война и Восток». Начало в 8 вечера. Сбор с лекции поступит на усиление средств Владикавказского местного отдела общества повсеместной помощи пострадавшим на войне солдатам и их семьям, состоящего под Высочайшим его Императорского Величества покровительством» [23]. Там же газета сообщала о том, что «... военный генерал-губернатор разрешил устроить в коммерческом собрании 12 апреля вечер-спектакль в пользу детского приюта для детей запасных и ратников ополчения, ушедших в действующие армии» [23].

Городское управление Владикавказа с самого начала войны обратило самое серьезное внимание на организацию таких приютов. Дпя ускорения процесса было решено опереться в этом деле на Владикавказское общество попечения о сиротах и бедных детях г. Владикавказа. Общество возглавлялось на тот момент Н. Я. Флейшер супругой Атамана Терского казачьего войска, Начальника Терской области, являвшейся председательницей и Владикавказского благотворительного общества. И одним из главным предметом заботы этого Общества был существовавший около 25 лет детский приют, содержание которого финансировалось основателем - бароном В. Р. Штейнгелем и Городским управлением Владикавказа. Поэтому Дума приняла решение “ под покровительством этого общества вблизи его собственного сиротского дома нанять помещение для сирот запасных, а в некоторых частях города устроить и дневные убежища...» [38; с. 126]. Решение это состоялось на позднее 1 октября 1914 г Владикавказское благотворительное общество, решая поставленную задачу по расширению сореры своих действий, пришло к необходимости «для объединения деятельности содержимых.. учреждений (детский приют, школа при нем, богадельня), приступить к постройке собственного здания.... [32; с. 82]. При этом первоначальный проект был пересмотрен в пользу предполагаемого к постройке приюта, « стем, чтобы в нем находились на призрении и дети-сироты лиц сельского состояния Терской области, пострадавших от войны» [38; с. 82]. Приют должен был вмещать 100 детей. Необходимость срочного решения проблемы привела руководство города и Общества к активной и успешной переписке с Романовским 
комитетом о скорейшем выделении последним субсидий на начатое строительство.

Н. Я. Флейшер на момент начала военных действий возглавляла и Владикавказский Комитет Красного Креста, имевший, как и другие местные его подразделения страны, достаточно большой опыт предыдущей деятельности и необходимый потенциал. Поэтому работа в условиях начавшихся военных действий была развернута очень оперативно

Bсе действия Владикавказского Комитета Красного Креста также во многом соотносились с деятельностью Кавказского Комитета ее императорского величества великой княгини Елизаветы Федоровны по оказанию благотворительной помощи пострадавшим от войны. Партнерами Владикавказского Комитета в работе в условиях военного времени были органы городского самоуправления, Владикавказское благотворительное общество, Владикавказское общество попечения о сиротах и бедных детях, женский Покровский монастырь, Свято-Троицкое братств и др. [15 c. 166]. В первый же год войны Комитет открыл во Владикавказе хирургическое отделение на 20 мест; создал и обеспечивал работу пункта питания в приемном помещении вокзала, распределяя затем раненых по городу; плотно занимался оказанием помощи семьям ушедших на фронт запасных; отправил в пользу раненых и больных воинов 500 комплектов белья.

Пятигорский Комитет Российского общества Красного Креста координировал работу колоний Красного Креста в гт. Железноводск и Ессентуки Георгиевской колонии Красного Креста, Георгиевской общины сестер милосердия, Дамского Комитета Красного Креста. Все названные колонии на период военных действий были перепрофилированы в лазареты для раненых солдат. В 1915 г Комитетом были развернуты и три лазарета для офицеров: в г. Пятигорске (на 85 мест), в ст. Ессентукской (на 250 мест), и Кисловодске (на 80 коек) $[10 ;$ с. 171]. На базе общины сестер милосердия в Георгиевске были открыты и успешно работали 4-месячные курсы по подготовке сестер милосердия. Благодаря этому за годы войны 140 девушек - медсестер из трех состоявшихся выпусков пополнили штат фронтовых лазаретов и госпиталей г. Пятигорска.

Еще одним важным направлением общественного участия в помощи пострадавшим от войны была работа с беженцами. К примеру, с 10 июня 1915 г., с момента опубликования в «Терских ведомостяХ» воззвания Владикавказского Комитета Всероссийского городского союза о необходимости щедрой помощи добрых людей, «чтобы не дать литовским беженцам, страдающим за общее дело, умереть от голода» [24], жители города потянулись в канцелярию Комитета во Владикавказе с пожертвованиями. После того, как в Петрограде в 1914 г. было зарегистрировано Общество вспомоществования бедным семействам поляков, участвующих в войне, и бедствующему населению, пострадавшему от военных действий [37; л. 2 - 6 об.], его отдел был открыт и активно работал в Терской области. В своей деятельности он руководствовался уставом петроградского общества [37; л. 2 - 6 об.].

Очевидно, что представленные отдельные факты из истории благотворительности Терской области в связи с участием России в Первой мировой войне свидетельствуют о том, что население и власти этого региона в деле помощи раненым, беженцам, семьям убитых и раненых, фронтовикам действовали солидарно со всей страной. Собирая пожертвования, открывая приюты, лазареты, мастерские для профессиональной реабилитации воинов-инвалидов, снабжая фронтовиков самым необходимым, помогая беженцам, готовя медсестер для работы в госпиталях, общество, в самых разных его слоях, и местная власть, вдохновляемые примером многих членов императорской фамилии, проявили единодушие в стремлении помочь стране и армии пережить время военных невзгод и лишений. Эти действия отвечали сложившимся в отечественной культуре на протяжении веков традициям милосердия и патриотизма.

\section{Источники и литература}

1. Атабиев Х. А. Терская область в годы Первой мировой войны: дисс. ... на канд. ист. наук. Владикавказ: СОГУ, 2016. $193 \mathrm{C}$.

2. Бадя Л. В. Благотворительность и меценатство в России. М.: Наука, 1993. 183 с.

3. Бесолова А. А. Становление и развитие благотворительности и общественного призрения Терского казачьего войска: дисс. ... канд. ист. наук. Владикавказ: СОГУ, 2008. 174 с.

4. Иванова Н. П. История благотворительности в России (вторая половина XIX - начало XX вв.). СПб.: [б. и.], , 1999 $119 \mathrm{c}$.

5. Кононова Т. Б. Особенности развития благотворительности в России. М.: МГСУ «Союз», 2002. 111 с.

6. Корниенко Т.А. Социальная повседневность населения Северного Кавказа в годы Первой мировой войны (август 1914 - февраль 1917 гг.): дисс. ... канд. ист. наук. Армавир: АГПИ, 2001. 313 с.

7. Краснокутский В. С., Краснокутская Л. И. Социальные инициативы женщин в заботе о жертвах и участниках Первой мировой войны (на примере Дамского Комитета Красного Креста города Пятигорска) // Общество: философия, история, культура. 2017. №2. С. 65-68.

8. Нагорная Ю. В. Российские женщины в благотворительном процессе второй половины XIX - начала XX веков: На материалах Терской области и Ставропольской губернии: дисс. ... канд. ист. наук. Ставрополь: СГУ, 2006. 277 с.

9. Нещеретный П. И. Исторические корни и традиции развития благотворительности в России. М.: Союз, 1993. 31 с

10. Омылаева Е. В. Благотворительная помощь на курортах КМВ в годы Первой мировой войны // Южные рубежи России. Материалы межрегиональной научно-практической конференции. Ставрополь, 17-19 ноября 2008 г. Ставрополь: СГУ, 2009. С. 171-173. 
11. Павлова И. П. Социальное попечение в России в конце XIX - начале XX вв. Красноярск: КГАУ, 2003. 152 с.

12. Павлова О. К. Предпринимательство, призрение и благотворительность в Санкт-Петербурге: вторая половина XIX - начало XX веков. СПб.: Изд-во Политехнического ун-та, 2007. $416 \mathrm{c}$.

13. Полное собрание узаконений и распоряжений Правительства, издаваемое при Правительствующем Сенате. Пг.: [б.и.], 1914. №224. Ст. 2239.

14. Покотилова Т. Е. Благотворительность в социальной истории дореволюционной России. М., 1997.185 с

15. Покотилова Т. Е. Война и благотворительность (по материалам Терской области 1914-1917 гг.) // Южные рубежи России. Материалы межрегиональной научно-практической конференции. Ставрополь, 17-19 ноября 2008 г Ставрополь: СГУ, 2009. С.166-168.

16. Покотилова Т. Е. Красный Крест на Северном Кавказе в годы Первой мировой войны (по материалам Ставропольской губернии и Терской области) // Боевое братство и национальное единство народов Северного Кавказа в годы Первой мировой войны. Материалы Международной научной конференции. Ставрополь: СКФУ, 2015. С. 143-147.

17. Покотилова Т. Е. Теоретико-методологический и историографический аспекты феномена российской благотворительности. Ставрополь: СГУ,1998. 95 с.

18. Скоч А. В. Меценатство и благотворительность в отечественном образовании XIX-XX веков. M.: ПЕР СЭ-Пресс, 2004. $331 \mathrm{c}$.

19. Соколов А. Р. Благотворительность в России как механизм взаимодействия общества и государства (начало XVIII - конец XIX века): дисс. ... докт. ист. наук. СПб.: СПБГУ, 2006. 648 с.

20. Соколов А. Р. Российская благотворительность в русском общественном сознании: Дореволюционная историография благотворительной деятельности и благотворительных учреждений. СПб.: Гиперион, 2005. 281 с.

21. Соколов А. Р. Благотворительность в народном образовании и ее роль в трансформации российского общества. СПб.: Лики России, 2006. 648 с.

22. Соколов А. Р. Российская благотворительность. Исторические исследования. СПб.: Гиперион, 2005.233 с

23. Терские ведомости. 1915. 10 апреля. №76.

24. Терские ведомости. 1915. 10 июня. №122.

25. Тигиев Ч. В. Благотворительная деятельность населения Терской области в годы Первой мировой войны // Научный диалог. 2016. №4(52). С. 65-69

26. Ульянова Г. Н. Благотворительная помощь общества жертвам войны в 1914-1918 гг: дискуссионные вопросы и содержание проблемы // Россия в годы Первой мировой войны. Материалы Международной научной конференции (Москва, 30 сентября - 3 ноября 2014 г.). М., 2014. С. 230-237.

27. Ульянова Г. Н. Благотворительность в Российской империи: XIX - начало XX века. М.: Наука, 2005.402 с.

28. Ульянова Г. Н. Изучение истории благотворительности в России: Тенденции и приоритеты (1989-2002) // Благотворительность в России. Исторические и социально-экономические исследования. Ежегодник 2002. СПб.: Лики России, 2003. С. 16-30.

29. Ульянова Г. Н. Изучение социальных аномалий, благотворительности и общественного призрения в России // Исторические исследования в России. Тенденции последних лет. М.: АИРО-ХХ, 1996. С. 405-426.

30. Ульянова Г. Н. Исследования истории благотворительности в России: тенденции последнего десятилетия // Милосердие и благотворительность в российской провинции: Пленарные доклады и материалы круглого стола всерос. научно-практич. конф. 22-23 марта 2002 г. Екатеринбург: Издательство Уральского университета, 2002. С. 15-25.

31. Ульянова Г. Н. История российской благотворительности в освещении историографии XIX - начала XX вв. // Вопросы истории. 2006. №1. С. 161-166.

32. Центральный государственный архив Республики Северная Осетия - Алания (далее - ЦГА РСО-Алания). Ф.11 Оп.11. Д. 295.

33. ЦГА РСО-Алания. Ф.11. ОП.52. Д.1569.

34. ЦГА РСО-Алания. Ф.17. Оп.1. Д.151

35. ЦГА РСО-Алания. Ф.193. ОП.1. Д.4.

36. ЦГА РСО-Алания. Ф.193. ОП.1. Д.7.

37. ЦГА РСО-Алания. Ф.199. ОП.1. Д.398.

38. ЦГА РСО-Алания. Ф.224. Оп.1. Д.131

\section{References}

1. Atabiev H. A. Terskaya oblast' v gody Pervoj mirovoj vojny (Terek Region during the First World War): thesis. Vladikavkaz: SOSU publ, 2016. 193 p. (In Russian).

2. Badya L. V. Blagotvoritel'nost' i mecenatstvo v Rossii (Charity and patronage in Russia). Moscow: Nauka, 1993. $183 \mathrm{p}$ (In Russian).

3. Besolova A. A. Stanovlenie i razvitie blagotvoritel'nosti i obshchestvennogo prizreniya Terskogo kazach'ego vojska (The Formation and Development of Charity and Public Charity of the Terek Cossack Army): thesis. Vladikavkaz: SOSU publ., 2008. 174 p. (In Russian).

4. Ivanova N. P. Istoriya blagotvoritel'nosti v Rossii (vtoraya polovina XIX - nachalo XX vv.) (The History of Charity in Russia (the Second half of the XIX - early XX Centuries). St.Petersburg, 1999. 119 p. (In Russian).

5. Kononova T. B. Osobennosti razvitiya blagotvoritel'nosti v Rossii (Features of the Development of Charity in Russia). Moscow: MGSU «Soyuz», 2002. 111 p. (In Russian).

6. Kornienko T. A. Social'naya povsednevnost' naseleniya Severnogo Kavkaza v gody Pervoj mirovoj vojny (avgust 1914 fevral' $1917 \mathrm{gg}$.) (Social Everyday Life of the Population of the North Caucasus during the First World War (August 1914 February 1917): thesis. Armavir: AGPI, 2001. 313 p. (In Russian). 
7. Krasnokutskij V. S., Krasnokutskaya L. I. Social'nye iniciativy zhenshchin v zabote o zhertvah i uchastnikah Pervoj mirovoj vojny (na primere Damskogo Komiteta Krasnogo Kresta goroda Pyatigorska) (Social Initiatives of Women in Caring for the Victims and Participants of the First World War (by the Example of the Ladies' Red Cross Committee of the City of Pyatigorsk) // Obshchestvo: filosofiya, istoriya, kul'tura. 2017. No.2. P. 65-68. (In Russian).

8. Nagornaya Yu. V. Rossijskie zhenshchiny $v$ blagotvoritel'nom processe vtoroj poloviny XIX - nachala XX vekov: Na materialah Terskoj oblasti i Stavropol'skoj gubernii (Russian Women in the Charity Process of the Second Half of the XIXEarly XX Centuries: On the Materials of the Terek region and the Stavropol Province): thesis. Stavropol': SSU publ., 2006. 277 p. (In Russian).

9. Neshcheretnyj P. I. Istoricheskie korni i tradicii razvitiya blagotvoritel'nosti v Rossii (Historical Roots and Traditions of the Development of Charity in Russia). Moscow: Soyuz,1993. 31 p. (In Russian).

10. Omylaeva E. V. Blagotvoritel'naya pomoshch' na kurortah KMV v gody Pervoj mirovoj vojny (Charitable Assistance in the Resorts of the CMW during the First World War) // YUzhnye rubezhi Rossii. Materialy mezhregional'noj nauchnoprakticheskoj konferencii. Stavropol', 17-19 noyabrya 2008 g. Stavropol': SSU publ., 2009. P. 171-173. (In Russian).

11. Pavlova I. P. Social'noe popechenie v Rossii v konce XIX - nachale XX vv. (Social Care in Russia in the Late XIXEarly XX Centuries). Krasnoyarsk: KSAU publ., 2003. 152 p. (In Russian)

12. Pavlova O. K. Predprinimatel'stvo, prizrenie i blagotvoritel'nost' $\vee$ Sankt-Peterburge: vtoraya polovina XIX - nachalo $X X$ vekov (Entrepreneurship, Charity and Charity in St. Petersburg: the Second Half of the XIX - Early XX Centuries). St.Petersburg: Politechnical University publ., 2007. 416 p. (In Russian).

13. Polnoe sobranie uzakonenij i rasporyazhenij Pravitel'stva, izdavaemoe pri Pravitel'stvuyushchem Senate (The Complete Collection of Laws and Orders of the Government Issued by the Governing Senate). Petrograd, 1914. No.224. Art. 2239. (In Russian).

14. Pokotilova T. E. Blagotvoritel'nost' v social'noj istorii dorevolyucionnoj Rossii (Charity in the Social History of Prerevolutionary Russia). Moscow, 1997. 185 p. (In Russian).

15. Pokotilova T. E. Vojna i blagotvoritel'nost' (po materialam Terskoj oblasti 1914-1917 gg.) (War and Charity (Based on Materials of the Terek region 1914-1917) // Yuzhnye rubezhi Rossii. Materialy mezhregional'noj nauchno-prakticheskoj konferencii. Stavropol', 17-19 noyabrya 2008 g. Stavropol': SSU publ., 2009. P. 166-168. (In Russian).

16. Pokotilva T. E. Krasnyj Krest na Severnom Kavkaze v gody Pervoj mirovoj vojny (po materialam Stavropol'skoj gubernii i Terskoj oblasti) (Red Cross in the North Caucasus during the First World War (Based on Materials of the Stavropol Province and the Terek region) // Boevoe bratstvo i nacional'noe edinstvo narodov Severnogo Kavkaza v gody Pervoj mirovoj vojny. Materialy Mezhdunarodnoj nauchnoj konferencii. Stavropol': NCFU publ., 2015. P. 143-147. (In Russian).

17. Pokotilova T. E. Teoretiko-metodologicheskij $\mathrm{i}$ istoriograficheskij aspekty fenomena rossijskoj blagotvoritel'nosti (Theoretical, Methodological and Historiographical Aspects of the Phenomenon of Russian Philanthropy). Stavropol': SSU publ., 1998. 95 p. (In Russian).

18. Skoch A. V. Mecenatstvo i blagotvoritel'nost' v otechestvennom obrazovanii XIX-XX vekov (Philanthropy and Charity in the Russian Education XIX-XX centuries). Moscow: PER SEH-Press, 2004. 331 p. (In Russian).

19. Sokolov A. R. Blagotvoritel'nost' v Rossii kak mekhanizm vzaimodejstviya obshchestva i gosudarstva (nachalo XVIII konec XIX veka): thesis (Charity in Russia as a Means of Society-state Cooperation (Early XVIII - Late XIX). St.Petersburg: SPBGU, 2006. 648 s. (In Russian).

20. Sokolov A. R. Rossijskaya blagotvoritel'nost'v russkom obshchestvennom soznanii: Dorevolyucionnaya istoriografiya blagotvoritel'noj deyatel'nosti i blagotvoritel'nyh uchrezhdenij (Russian Charity in the Russian Public Consciousness: PreRevolutionary Historiography of Charitable Activities and Charitable Institutions). St.Petersburg: Giperion, 2005. 281 p. (In Russian).

21. Sokolov A. R. Blagotvoritel'nost' v narodnom obrazovanii i ee rol' v transformacii rossijskogo obshchestva (Charity in Public Education and Its Role in the Transformation of Russian Society). St.Petersburg: Liki Rossii, 2006. 648 p. (In Russian).

22. Sokolov A. R. Rossijskaya blagotvoritel'nost'. Istoricheskie issledovaniya (Russian Charity. Historical Research). St.Petersburg: Giperion, 2005. 233 p. (In Russian).

23. Terskie vedomosti. 1915. April 10. No. 76. (In Russian).

24. Terskie vedomosti. 1915. June 10. No. 122. (In Russian).

25. Tigiev Ch. V. Blagotvoritel'naya deyatel'nost' naseleniya Terskoj oblasti v gody Pervoj mirovoj vojny (Charitable Activities of the Population of the Terek Region during the First World War) // Nauchnyj dialog. 2016. No. 4(52). P. 65-69. (In Russian).

26. Ul'yanova G. N. Blagotvoritel'naya pomoshch' obshchestva zhertvam vojny v 1914-1918 gg.: diskussionnye voprosy i soderzhanie problem (Charitable Assistance of the Society to the Victims of the War in 1914-1918: Disputible Questions and the Content of the Problem) // Rossiya v gody Pervoj mirovoj vojny. Materialy Mezhdunarodnoj nauchnoj konferencii (Moskva, 30 sentyabrya -3 noyabrya 2014 g.). Moscow, 2014. P. 230-237. (In Russian).

27. Ul'yanova G. N. Blagotvoritel'nost' v Rossijskoj imperii: XIX - nachalo XX veka (Charity in the Russian Empire: XIXEarly XX). Moscow: Nauka, 2005. 402 p. (In Russian).

28. Ul'yanova G. N. Izuchenie istorii blagotvoritel'nosti $\vee$ Rossii: Tendencii i prioritety (1989-2002) (Studying the History of Philanthropy in Russia: Trends and Priorities (1989-2002) // Blagotvoritel'nost' v Rossii. Istoricheskie i social'noehkonomicheskie issledovaniya. Ezhegodnik 2002. St.Petersburg: Liki Rossii, 2003. P. 16-30. (In Russian).

29. UI'yanova G. N. Izuchenie social'nyh anomalij, blagotvoritel'nosti i obshchestvennogo prizreniya $\vee$ Rossii (Study of Social Anomalies, Charity and Public Charity in Russia) // Istoricheskie issledovaniya v Rossii. Tendencii poslednih let. Moscow: AIRO-HKH, 1996. P. 405-426. (In Russian).

30. Ul'yanova G. N. Issledovaniya istorii blagotvoritel'nosti v Rossii: tendencii poslednego desyatiletiya (Studies of the History of Philanthropy in Russia: the Trends of the Last Decade) // Miloserdie i blagotvoritel'nost' $v$ rossijskoj provincii: Plenarnye doklady i materialy kruglogo stola vseros. nauchno-praktich. konf. 22-23 marta $2002 \mathrm{~g}$. Ekaterinburg: Izdatel'stvo Ural'skogo universiteta, 2002. P. 15-25. (In Russian). 
31. UI'yanova G. N. Istoriya rossijskoj blagotvoritel'nosti v osveshchenii istoriografii XIX - nachala XX vv. (Studies of the History of Philanthropy in Russia: the Trends of the Last Decade) // Voprosy istorii. 2006. No.1. P. 161-166. (In Russian).

32. Central State of Republic of North Ossetia-Alania (CGA RSO-Alaniya). F.11. Inv.11. D.295. (In Russian).

33. CGA RSO-Alaniya. F.11. Inv.52. D.1569. (In Russian).

34. CGA RSO-Alaniya. F.17. Inv.1. D.151. (In Russian).

35. CGA RSO-Alaniya. F.193. Inv.1. D.4. (In Russian).

36. CGA RSO-Alaniya. F.193. Inv.1. D.7. (In Russian).

37. CGA RSO-Alaniya. F.199. Inv.1. D.398. (In Russian).

38. CGA RSO-Alaniya. F.224. Inv.1. D.131. (In Russian). 